\title{
Host-seeking behavior of the Heterorhabditis amazonensis nematode in response to stimulant sources ${ }^{1}$
}

\author{
Vanessa Andaló ${ }^{2}$, Grazielle Furtado Moreira ${ }^{3}$, Alcides Moino Junior ${ }^{4}$
}

\section{ABSTRACT}

Several species of entomopathogenic nematodes have different host-seeking methods, and could be considered as "ambusher" or "cruiser". These differences may depend on how the nematodes detect the volatile signals used as cues for foraging. This study aimed to evaluate the locomotor response of Heterorhabditis amazonensis RSC5 to the compounds from root exudates of different plants, as well as to stimulants produced by the presence of insects or to the feeding activity of insects on plants. Arenas with agar-water substrates, containing root exudates from corn, bean, soybean, cucumber, garlic and tomato seedlings, were assembled to determine the substrates possibly preferred by $H$. amazonensis. Arenas with sand were also constructed to include, besides the seedling root exudates, treatments containing Spodoptera frugiperda, garlic seedlings and $S$. frugiperda feeding on garlic seedlings. The $H$. amazonensis species was attracted to the volatile chemicals emitted by all the root exudates tested, especially the exudate from garlic seedlings. However, it showed the greatest attraction to the combination of garlic seedlings and $S$. frugiperda, indicating that the search of $H$. amazonensis for its host is enhanced by the association between the insect and the volatile chemical compounds produced by plants, when attacked by insects.

KEYWORDS: Spodoptera frugiperda; chemical cues; root exudates; volatile plant compounds.

\section{INTRODUCTION}

Plants and insects have coexisted for approximately 350 million years and have developed elaborate systems that highlight the tritrophic interplay among plants, insect herbivores and their natural enemies. Just as plants can attract predators and parasitoids, including natural enemies, they can also interact with pathogens (Elliot et al. 2000). The ability to attract natural enemies is referred to

\section{RESUMO}

Comportamento de busca do nematoide Heterorhabditis amazonensis em relação a fontes de estímulo

Muitas espécies de nematoides entomopatogênicos apresentam diferenças no modo de busca pelo seu hospedeiro, podendo ser consideradas como "ambusher" ou "cruiser". Essas diferenças podem depender de como esses nematoides detectam os sinais voláteis utilizados como dicas para o forrageamento. Objetivou-se avaliar a resposta locomotora de Heterorhabditis amazonensis RSC5 à liberação de compostos provenientes de exsudatos radiculares de diferentes plantas, ao estímulo produzido pela presença do inseto ou à atividade alimentar do inseto na planta. Foram montadas arenas com substrato ágar-água, contendo exsudatos radiculares de plântulas de milho, feijoeiro, soja, pepino, alho e tomateiro, para verificação de possível escolha por H. amazonensis, bem como em areia contendo, além do exsudato radicular das plântulas, tratamentos com Spodoptera frugiperda, plântula de alho e plântula de alho juntamente com $S$. frugiperda. A espécie $H$. amazonensis foi atraída pelas substâncias químicas voláteis emitidas por todos os exsudatos radiculares testados, principalmente aquele obtido da plântula de alho. No entanto, a maior atração ocorreu quando exposta ao tratamento com plântula de alho associada a $S$. frugiperda, o que evidencia que H. amazonensis se beneficia da associação entre a presença do inseto e os compostos químicos voláteis produzidos pela planta, quando atacada por ele.

PALAVRAS-CHAVE: Spodoptera frugiperda; chaves químicas; exsudatos radiculares; compostos voláteis de plantas.

as a type of induced resistance (defense), in which the attacked plant produces and releases volatile chemicals that serve as signals to attract natural enemies (Walton 1997).

Roots are likely the most suitable region of the plant for entomopathogens of soil pests to attack, because the soil is rich in microorganisms that can suppress the population of insects that feed on roots in natural ecosystems (Rasmann et al. 2005). Entomopathogenic nematodes are potential natural

1. Manuscript received in Feb./2017 and accepted for publication in Aug./2017 (http://dx.doi.org/10.1590/1983-40632016v4745395). 2. Universidade Federal de Uberlândia, Instituto de Ciências Agrárias, Monte Carmelo, MG, Brasil. E-mail: vanessaandalo@ufu.br. 3. Universidade de São Paulo, Departamento de Entomologia e Acarologia, Piracicaba, SP, Brasil. E-mail: grabiologia@yahoo.com.br. 4. Universidade Federal de Lavras, Departamento de Entomologia, Lavras, MG, Brasil.E-mail: alcmoino@ufla.br. 
enemies of agricultural insect pests and have been used in various pest control programs (Dolinski et al. 2012). They can use several mechanisms to locate their insect hosts (Lewis et al. 2006, Griffin 2012). The nematode host-seeking behavior and its infective capacity may be affected by many factors, including soil characteristics and types (Kruitbos et al. 2010), electrical current and substrate vibration (Torr et al. 2004, Shapiro-Ilan et al. 2009) and the infective juveniles search strategy ("ambusher" and “cruiser") (Gaugler et al. 1997).

Plant roots attacked by insects produce signals that can attract entomopathogenic nematodes in the rhizosphere (Turlings et al. 2012). Recent evidence has shown that several species of entomopathogenic nematodes have taken advantage of the volatile compounds emitted by plant roots being attacked by insects to locate the insects, even over long distances. Carbon dioxide $\left(\mathrm{CO}_{2}\right)$ in the soil indicates a biological activity and has been widely implicated in locating a host (Rasmann et al. 2012). Turlings et al. (2012) reported that the combination of this gas and specific volatile root compounds is more attractive than when encountered individually, acting synergistically to attract entomopathogenic nematodes.

Entomopathogenic nematodes use various methods to host seeking, and these methods may depend on how they detect the volatile compounds used as cues for foraging. The classification of entomopathogenic nematode species as "cruisers" or "ambushers" may vary, and several species use both behaviors (Wilson et al. 2012). Some nematodes search for hosts that are close to the soil surface [Steinernema carpocapsae (Weiser) Wouts, Mracek, Gerdin \& Bedding and Steinernema scapterisci Nguyen \& Smart], being called "cruisers", which have a great mobility and infect a wide range of hosts. Others are adapted to a deeper search in the soil [Heterorhabditis bacteriophora Poinar and Steinernema glaseri (Steiner) Wouts, Mracek, Gerdin \& Bedding], being called "ambushers", which act when the host moves on the soil surface, using a mechanism known as "nictating" (Grewal et al. 2001).

A better understanding of the behavior and locomotion of entomopathogenic nematodes is important to successfully using them in pest control programs. Based on the information provided, plant roots, as well as the presence of insects feeding on them, may attract nematodes, so they can locate the host through volatile cues issued by the plant, as well as by the insect or by the association of both.

Thus, this study aimed at evaluating the locomotor response of the Heterorhabditis amazonensis strain RSC5 Andaló, Nguyen and Moino Junior, 2006 (Rhabditida: Heterorhabditidae), a potential entomopathogenic nematode for controlling insectpests in Brazil, to root exudates of various plants and to stimulants produced by insects or by the feeding activity of insects on plants, in order to verify their seeking behavior.

\section{MATERIAL AND METHODS}

Heterorhabditis amazonensis RSC5 was isolated from soil in Benjamin Constant, Amazonas state, Brazil (Andaló et al. 2006), and maintained in Erlenmeyer flasks containing 500-1,000 infective juveniles $\mathrm{mL}^{-1}$, in an aqueous suspension, and then placed in an incubator at $16 \pm 1{ }^{\circ} \mathrm{C}$, for at most two months. For use in the experiments, the infective juveniles were multiplied in Galleria mellonella (Linnaeus) (Lepidoptera: Pyralidae), which was reared at the Universidade Federal de Lavras, using an artificial diet modified by Parra (1998). Some of the experiments were performed using Spodoptera frugiperda (Smith) (Lepidoptera: Noctuidae) at the third instar, being chosen because of its polyphagous habit and its potential as a pest on several cultivated plants. The initial colony was established with the larvae obtained from corn plants in Lavras, Minas Gerais state, Brazil. The larvae were reared according to Bowling (1967).

Soybean [Glycine max (L.) Merrill], bean (Phaseolus vulgaris L.), corn (Zea mays L.), cucumber (Cucumis sativus L.), pepper (Capsicum annuum L.) and tomato (Lycopersicon esculentum Mill.) seeds were sown in polystyrene trays to produce seedlings (288 cells, $680 \mathrm{~mm}$ x $344 \mathrm{~mm}$ x 47 mm outer dimensions), using Plantmax ${ }^{\circledR}$ (company Buschle \& Lepper S.A.) as the substrate, and garlic (Allium sativum L.) bulbs were planted in a total of 60 plants for each species. These plants were tested because they are important crops in Brazil and are affected by many insect-pests such as $S$. frugiperda, Diabrotica speciosa (Germar) (Coleoptera: Chrysomelidae) and Agrotis ipsilon (Hufnagel) (Lepidoptera: Noctuidae). These important pests may be potentially controlled by entomopathogenic nematodes. The trays were maintained in a growth 
chamber with a 14-h photophase and temperature of $28 \pm 2{ }^{\circ} \mathrm{C}$. The seedlings were removed after different growth periods to generate the exudates: garlic and corn seedlings at 5-days-old; cucumber seedlings at 6-days-old; soybean and bean seedlings at 8-days-old; and tomato seedlings at 13-days-old. These different periods are related to the difference in germination and growth of the plant species used in order to allow standardization in size.

For each plant type, 20 tubes were prepared, putting $7 \mathrm{~mL}$ of sterile distilled water in $20 \mathrm{~mL}$ flatbottomed glass tubes. The seedlings were removed from the trays and their roots were gently washed and placed individually in the glass tubes. These tubes were placed in a climate-controlled chamber, at $24{ }^{\circ} \mathrm{C} \pm 2{ }^{\circ} \mathrm{C}$, for approximately $10 \mathrm{~h}$. To generate the root exudates, the solutions were removed and filtered, and the exudates were prepared in Becker cups. The exudates were filtered twice, using sterile Millipore $^{\circledR}$ membranes of $5 \mu \mathrm{m}$ and $0.22 \mu \mathrm{m}$ pore sizes. The exudates were stored in Eppendorf tubes and frozen at $-20{ }^{\circ} \mathrm{C}$, for subsequent use (Andaló et al. 2012).

In the one-choice test, the displacement of H. amazonensis RSC5 infective juveniles was evaluated in relation to the type of plant root exudate (corn, bean, soybean, cucumber, garlic and tomato). In total, $0.3 \mathrm{~mL}$ containing 510 infective juveniles was applied per plate to one side of a Petri dish $(15 \mathrm{~cm})$ containing $1 \%$ water-agar. Then, $50 \mu 1$ of root exudate were applied to the opposite side of the dish. At the point where the exudate was applied, a $0.1 \mathrm{~cm} \times 0.1 \mathrm{~cm}$ hole was carved in the agar to prevent the exudate from spreading over the dish. Therefore, the distance of the exudate from the infective juveniles was approximately $15 \mathrm{~cm}$. The nematodes counted as attracted were those that came within at least $1 \mathrm{~cm}$ of the exudates. Ten replicates were performed per treatment. The control treatments included water and the nematicide aldicarb, at a concentration of $50 \mathrm{ppm}$, both applied at a volume of $0.3 \mathrm{~mL}$. The evaluations of infective juveniles displacement were performed with the use of a stereoscopic microscope, after $12 \mathrm{~h}$ of incubation at $24{ }^{\circ} \mathrm{C} \pm 1{ }^{\circ} \mathrm{C}$, relative humidity of $70 \pm 10 \%$, with a $24-\mathrm{h}$ scotophase, in a climatecontrolled chamber.

A multi-choice test was established preparing an arena with all the treatments, and the preferences for the different exudates were determined. For this test, the assays were performed under the same conditions, but the infective juveniles were free to choose among exudates. The Petri dishes were divided into eight equal parts to distribute the treatments (six root exudates, plus water and aldicarb). The divisions were made using polystyrene plastic strips, so that each area was $22.1 \mathrm{~cm}^{2}$. The 510 infective juveniles were released in the center of the dish. In total, 15 replicates were performed to determine the displacement toward certain exudates, over a 12-h incubation period.

The Heterorhabditis amazonensis preference was also measured using a choice test in sand arena toward different seedlings, including corn, bean, cucumber, garlic, soybean and tomato. The seedlings were prepared as described above to generate the root exudates. For these assays, round plastic pots (45 $\mathrm{cm}$ in diameter and volume of approximately $11.13 \mathrm{~cm}^{3}$ ) were used. Eight circular holes were made in the side of each plastic pot and a polyvinyl chloride (PVC) with $50 \mathrm{~mm}$ diameter elbow $\left(90^{\circ}\right)$ was attached to each hole. The PVC elbows were filled with sand and the seedlings were transferred to them (one seedling per elbow) (Figure 1A). As control treatments, distilled water was applied to one elbow and the nematicide aldicarb to another, totaling eight treatments. So, in each plastic pot, eight elbows were attached, which represent the treatments, one for each seedling (a total of six) and two for the control treatments (distilled water and aldicarb).

In total, $5.4 \mathrm{~kg}$ of sterile sand were added to each plastic pot and $100 \mathrm{~g}$ to each elbow. In addition, $500 \mathrm{~mL}$ of water were added per pot, and $25 \mathrm{~mL}$ of water were added per elbow, to keep the sand moisture. The infective juveniles were released in the center of the plastic container, in a $5 \mathrm{~mL}$ suspension of 2,000 infective juveniles $\mathrm{mL}^{-1}$. The seedlings were transplanted into the elbows at $48 \mathrm{~h}$ prior to releasing the nematodes into the pot and then watered daily with $5 \mathrm{~mL}$ of water (until the evaluation period of the experiment), to ensure that the seedlings were established. In one of the control elbows, $0.2 \mathrm{~mL}$ of aldicarb was added at a concentration of $50 \mathrm{ppm}$, and $5 \mathrm{~mL}$ of water were added to the other control elbow. In total, 15 replicates were performed. The evaluations were performed at $48 \mathrm{~h}$ after the release of the infective juveniles (establishment of the experiment).

To evaluate the experiment, the nematodes needed to be recovered from the sand. To accomplish this, the sand was sifted through three sieves. First 
through a 60 -mesh sieve, followed by an 80 -mesh sieve and then a 500-mesh sieve, to retain the infective juveniles. The nematodes were collected and placed in $20 \mathrm{~mL}$ of an aqueous suspension, in $100-\mathrm{mL}$ plastic pots. Subsequently, the suspension was placed in a 9-cm diameter Petri dish and divided into fields, to count the number of infective juveniles, using a stereoscopic microscope. The number of infective juveniles per elbow, i.e., the number of infective juveniles attracted to each treatment, was determined.

The same methodology was used to evaluate the infective juveniles displacement direction, with respect to garlic seedlings, $S$. frugiperda larvae, garlic plant root exudates and $S$. frugiperda larvae feeding on garlic seedlings (based on the results of previous tests) (Andaló et al. 2014). The $S$. frugiperda larvae were buried in the sand at $24 \mathrm{~h}$ after the seedlings were transplanted, allowing them to be established. The nematodes were released at $24 \mathrm{~h}$ after that, giving $S$. frugiperda enough time to start feeding on seedlings (Figures 1B and 1C). Distilled water and aldicarb (50 ppm) were used as controls for a total of six treatments. For these experiments, two of the elbow tubes attached to the plastic containers used in the assay described above were removed, and the remaining holes were sealed with tape, so that there were only six elbows (one for each treatment). The evaluations were performed at $48 \mathrm{~h}$ after the release of the infective juveniles. The assumptions of normality and homogeneity of variance were tested with the Shapiro-Wilks and Levene tests, respectively, at $1 \%$. The data were submitted to analysis of variance (Anova) and to the Tukey test $(p<0.05)$, for comparisons between means.

\section{RESULTS AND DISCUSSION}

When the displacement of the $H$. amazonensis infective juveniles was measured using the onechoice test in Petri dishes containing water-agar, they were attracted to all the root exudates (cucumber, tomato, garlic, bean, soybean and corn). The infective juveniles were rarely found near the controls containing aldicarb or water (Figure 2). The infective juveniles moved toward all the exudates tested, what indicates that they recognized the exudates as a source of stimulation. However, there were differences in the data obtained for the exudates. The garlic plant root exudates attracted the largest number of infective juveniles, followed by the tomato seedling root exudates, cucumber and soybean root exudates, and, finally, the root exudates from the corn and bean seedlings. These percentages of infective juveniles were all different from the percentages of infective juveniles attracted to the control treatments $(\mathrm{F}=543.81 ;$ d.f. $=7 ; \mathrm{p}<0.01)$ (Figure 2$)$.

According to Hallem et al. (2011), the chemical signals emitted by the entomopathogenic nematodes host insects are key factors that allow entomopathogenic nematodes to locate their hosts. However, the substances used by entomopathogenic nematodes to find their hosts, including $\mathrm{CO}_{2}$, may be emitted by either the host or the plant roots, and these substances may be detected by the nematodes, demonstrating either "cruiser" or "ambusher" behavior. Thus, the H. amazonensis nematode, which exhibits a behavior similar to "cruiser" nematodes (Gaugler et al. 1997), successfully used the substances released by the seedling root tested, the exudates, for orientation purposes, what might help it to find host insects.
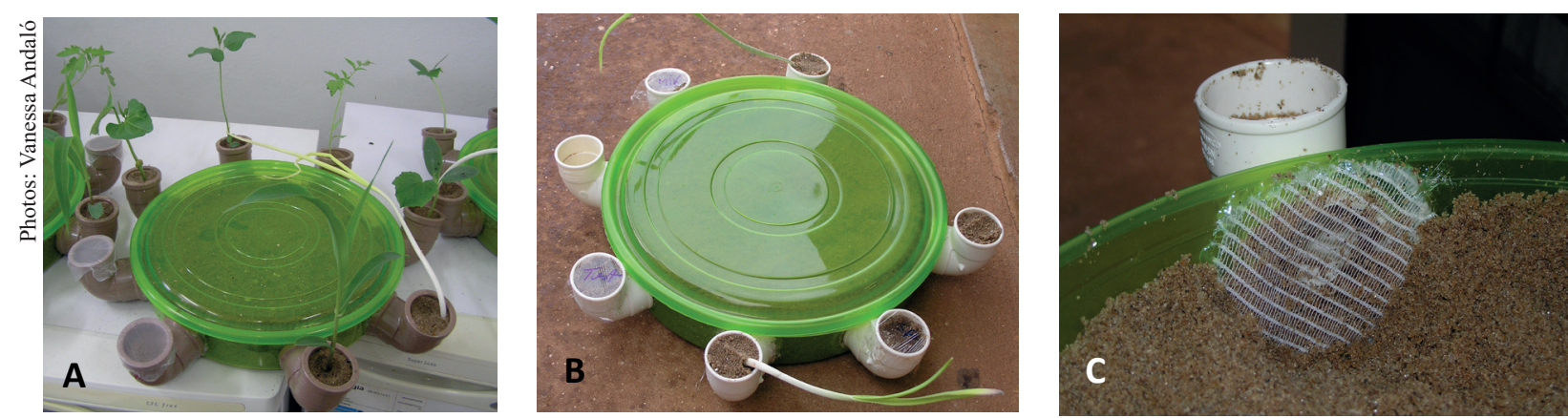

Figure 1. Arenas used to evaluate the choice tests in sand. A) Choice test toward different seedlings; B and C) multi-choice test, considering garlic and Spodoptera frugiperda. 
For the multi-choice test using H. amazonensis infective juveniles and different root exudates (cucumber, tomato, garlic, bean, soybean and corn) and control treatments (water and aldicarb), in Petri dishes containing water-agar, the infective juveniles showed a preference for the root exudates over the control treatments. There were also preferences among the exudates (Figure 3$)(F=60.23$; d.f. $=7$; $\mathrm{p}<0.01$ ). Most of the infective juveniles released on the dish were attracted toward the garlic seedling root exudate, followed by exudates from the tomato, bean, cucumber, corn and soybean seedling exudates. These results indicate that the infective juveniles recognized all the exudates as stimulant sources, which directed

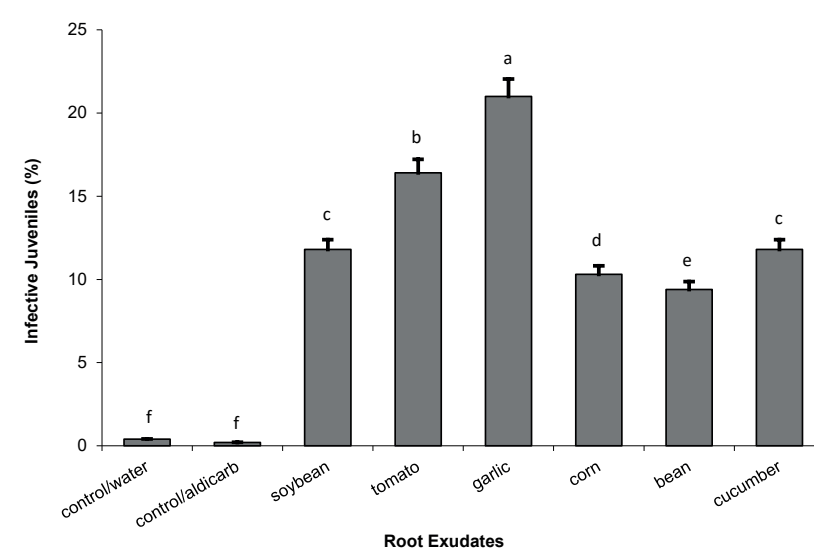

Figure 2. Displacement of Heterorhabditis amazonensis (\%) (means $\pm 95 \% \mathrm{CI}$ ) in the one-choice tests using root exudates and control treatments with water and aldicarb. Means followed by the same letter do not differ by the Tukey test $(n=10 ; p<0.01 ; C V \%=52.3)$.

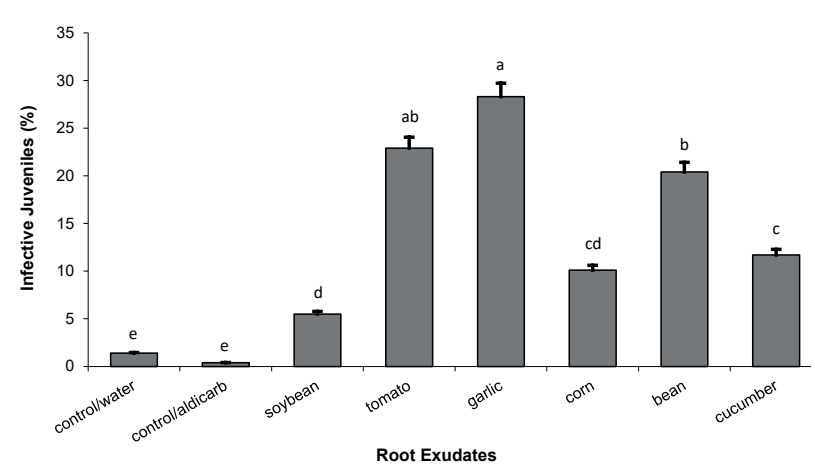

Figure 3. Preference of Heterorhabditis amazonensis (\%) (means $\pm 95 \% \mathrm{CI}$ ), in multi-choice tests using root exudates and control treatments with water and aldicarb. Means followed by the same letter do not differ by the Tukey test $(n=15 ; \mathrm{p}<0.01 ; \mathrm{CV} \%=47.9)$. their host-seeking behavior. When these stimuli are available alternatively, there is a preference for some root exudates over others, with garlic $(28.3 \%)$ and tomato $(22.9 \%)$ being the preferred ones (Figure 3 ).

Thus, the root exudates may have acted as initial activators in the search for a host by the infective juveniles, because, in these experimental conditions, only substances released by the plants were emitted, not those released by the insects. The garlic and tomato seedlings may have released these signals in greater quantities. Similar observations can be seen with the control treatments, where there was no stimulus to warrant movement toward these treatments.

According to Ramos-Rodriguez et al. (2007), nematodes use various chemical cues to find hosts, and these substances, such as $\mathrm{CO}_{2}$, may not necessarily be released by the host. Therefore, these cues can be unreliable, because they are emitted by many different sources, including non-host insects, and in various quantities. Turner et al. (2011) also pointed out that some substances may act only as alert activators for the nematode, encouraging it to search for more specific and reliable cues, following the first perception of a living organism.

In evaluating the preference of $H$. amazonensis toward different stimulant sources in arenas containing sand, the infective juveniles displaced toward all the treatments containing plant seedlings. There was a significant difference between the percentage of infective juveniles near the treatment containing garlic seedlings $(48.4 \%)$ and the other treatments. The treatments with water $(0.1 \%)$ and aldicarb $(0.1 \%)$ differed from the other treatments, with the least preference of juveniles (Figure 4$)(\mathrm{F}=$ 228.81 ; d.f. $=7 ; \mathrm{p}<0.01$ ).

Nematodes of the Heterorhabditis genus are known for their "cruiser" host-seeking behavior and, according to Lewis et al. (2006), these nematodes spend a significant amount of time seeking cues associated with their hosts. They move throughout their environment and take only small breaks in the search process. "Cruiser" nematodes are highly influenced by chemical cues released into the environment and are more likely to find stimulant sources than sedentary "ambusher" nematodes (which spend most of their time waiting for a host to pass). Thus, the volatile compounds released by garlic seedlings may have predominated over the other compounds and caused more H. amazonensis infective juveniles to move toward garlic extracts. 
When the preference of $H$. amazonensis was measured for the different stimulant sources in the arenas with sand, which included the garlic seedlings, the $S$. frugiperda larvae, the garlic seedlings associated with $S$. frugiperda and the seedling and garlic root exudates, there were significant differences among the treatments. The combination of the garlic seedlings and $S$. frugiperda attracted the highest percentage of infective juveniles $(60.3 \%)$ (Figure 5) $(F=676.79 ;$ d.f. $=5 ; p<0.01)$. No infective juveniles were found in the sand samples containing the water and aldicarb control treatments.

Treatments containing the garlic seedlings, $S$. frugiperda or garlic seedling root exudates also

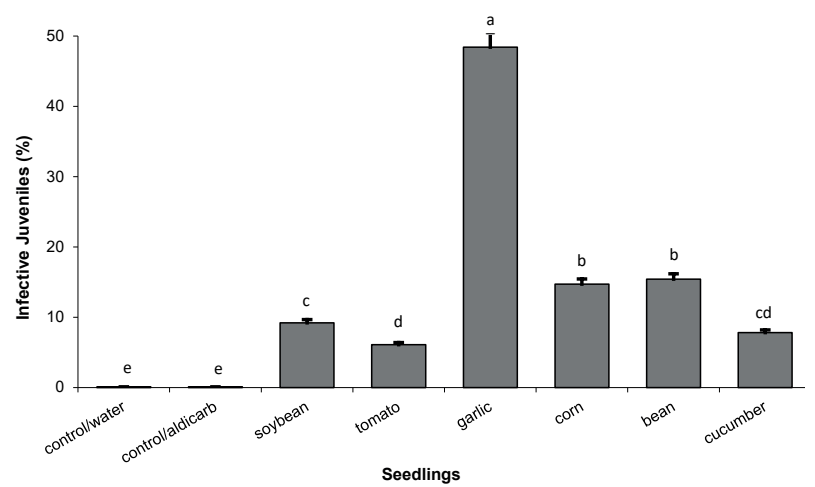

Figure 4. Preference of Heterorhabditis amazonensis (\%) (means $\pm 95 \% \mathrm{CI}$ ), in the multi-choice tests in arenas containing sand. Means followed by the same letter do not differ by the Tukey test $(n=15 ; \mathrm{p}<0.01$; $\mathrm{CV} \%=32.1$ ).

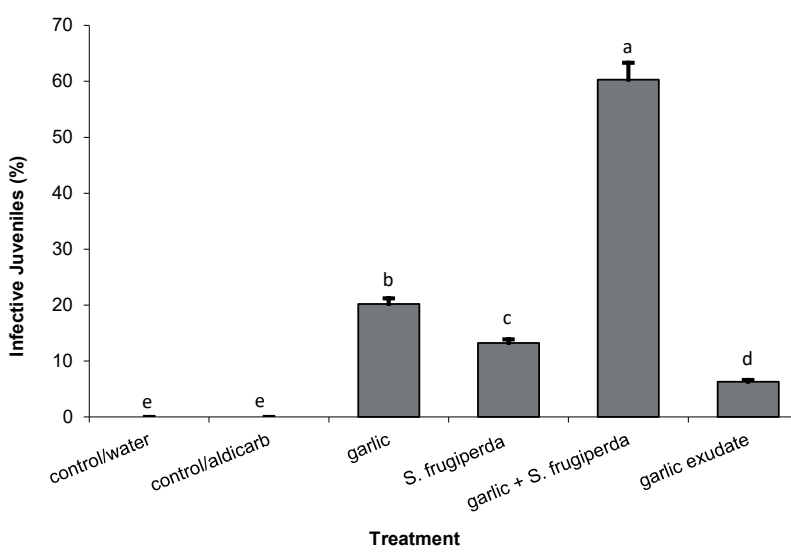

Figure 5. Preference of Heterorhabditis amazonensis (\%) (means $\pm 95 \% \mathrm{CI}$ ), in the multi-choice test conducted in arenas containing sand. Means followed by the same letter do not differ by the Tukey test $(n=15$; $\mathrm{p}<0.01 ; \mathrm{CV} \%=20.3)$. attracted infective juveniles, indicating that the nematode moved toward these chemical signals (Figure 5). According to Boff et al. (2002), nematodes respond to plant roots damaged by insects. Van Tol et al. (2001) reported that the nematode Heterorhabditis megidis Poinar, Jackson and Klein 1987 (Rhabditida: Heterorhabditidae) was attracted considerably more strongly to exudates released from roots of the Thuja occidentalis L. conifer when it was attacked by larvae of the Otiorhynchus sulcatus (Fabricius, 1775) (Coleoptera: Curculionidae) beetle.

Ali et al. (2010 and 2011) demonstrated that multiple species of entomopathogenic nematodes are highly attracted to the roots of citrus plants damaged by the feeding of Diaprepes abbreviatus (Linnaeus) (Coleoptera: Curculionidae) larvae. Roots infested and damaged by insects were more attractive to nematodes than those that were mechanically damaged or by the larvae alone. Terpene compounds have been found in the roots of plants damaged by insects, but not in non-infested roots or in soil containing only the insect. Rasmann et al. (2005 and 2011) and Hiltpold et al. (2010) identified a substance $[(\mathrm{E})-\beta$-caryophyllene] that strongly attracts $H$. megidis. This sesquiterpene is released by the roots of corn plants in response to Diabrotica virgifera LeConte (Coleoptera: Chrysomelidae) feeding, which attracts entomopathogenic nematodes to the pests, increasing the potential for control.

Volicitin is a substance found in the oral secretions of Spodoptera exigua (Hübner) (Lepidoptera: Noctuidae) that has been associated with the induction of volatile compounds in corn plants (Turlings et al. 2000). Insect feeding may attract nematodes via both the release of volatile compounds and the transmission of vibrations. However, "cruiser" nematodes, such as Heterorhabditis, are strongly attracted by the roots on which insects are feeding, mainly due to the release of allelochemicals (Lewis et al. 1995). Thus, according to the results of this study, the feeding of the $S$. frugiperda larvae on garlic seedlings may have released compounds that were strongly attractive for the entomopathogenic nematodes, what may increase the potential for pest control. These compounds could be released as a result of $S$. frugiperda feeding on garlic. Even though this insect is not a soil pest, it was used as a model, indicating the changes that the feeding on plant roots can provide in the chemical components in the soil, since it triggered alterations in the nematode search. 
These data are consistent with those reported by Ennis et al. (2010), who found that Picea sitchensis (Pinaceae), particularly when damaged by Hylobius abietis (Linnaeus) (Coleoptera: Curculionidae), form a chemical route for $S$. carpocapsae to find the host. According to Hiltpold \& Turlings (2012), roots interfere in the dynamic of belowground herbivores, since they produce chemical exudates. Understanding the action of these chemical signals may help to increase the defenses of plants against insect pests.

Andaló et al. (2010) reported the control of $S$. frugiperda under laboratory and greenhouse conditions. Given that $H$. amazonensis is highly attracted to volatile chemicals emitted by plant roots, particularly plants associated with insects, this strategy may be used to establish pest management practices and to understand how entomopathogenic nematodes use chemical signals from their hosts and plants to orient themselves. This knowledge may then be used to improve pest management practices.

\section{CONCLUSION}

Heterorhabditis amazonensis is attracted to volatile chemical compounds emitted by all the root exudates, especially garlic seedlings. However, the highest levels of attraction are generated when the entomopathogenic nematodes are exposed to treatments containing garlic seedlings associated with $S$. frugiperda.

\section{ACKNOWLEDGMENTS}

The authors would like to thank the Conselho Nacional de Desenvolvimento Científico e Tecnológico $(\mathrm{CNPq})$ and Fundação de Amparo à Pesquisa do Estado de Minas Gerais (Fapemig), for financial support.

\section{REFERENCES}

ALI, J. G.; ALBORN, H. T.; STELINSKI, L. L. Constitutive and induced subterranean plant volatiles attract both entomopathogenic and plant parasitic nematodes. Journal of Ecology, v. 99, n. 1, p. 26-35, 2011.

ALI, J. G.; ALBORN, H. T.; STELINSKI, L. L. Subterranean herbivore induced volatiles released by citrus roots upon feeding by Diaprepes abbreviatus recruit entomopathogenic nematodes. Journal of Chemical Ecology, v. 36, n. 4, p. 361-368, 2010.
ANDALÓ, V. et al. Evaluation of entomopathogenic nematodes under laboratory and greenhouse conditions for the control of Spodoptera frugiperda. Ciência Rural, v. 40, n. 9, p. 1860-1866, 2010.

ANDALÓ, V. et al. In vivo and in vitro study of the effects of entomopathogenic bacteria and their filtrates on Meloidogyne incognita. International Research Journal of Microbiology, v. 3, n. 1, p. 5-9, 2012.

ANDALÓ, V.; MOREIRA, G. F.; MOINO JUNIOR, A. Heterorhabditis amazonensis RSC5 (Rhabditida: Heterorhabditidae) displacement and host recognition. Revista Colombiana de Entomologia, v. 40, n. 1, p. 9197, 2014.

ANDALÓ, V.; NGUYEN, K. B.; MOINO JUNIOR, A. Heterorhabditis amazonensis $\mathrm{n}$. sp. (Rhabditida: Heterorhabditidae) from Amazonas, Brazil. Nematology, v. 8, n. 6, p. $853-867,2006$.

BOFF, M. I. C. et al. Behavioural response of Heterorhabditis megidis towards plant roots and insect larvae. BioControl, v. 47, n. 1, p. 67-83, 2002.

BOWLING, C. C. Rearing of two lepidopterous pests of rice on common artificial diet. Annals of the Entomological Society of America, v. 60, n. 6, p. 1215-1216, 1967.

DOLINSKI, C.; CHOO, H. Y.; DUNCAN, L. W. Grower acceptance of entomopathogenic nematodes: case studies on three continents. Journal of Nematology, v. 44, n. 2, p. 226-235, 2012.

ELLIOT, S. L. et al. Can plants use entomopathogens as bodyguards? Ecology Letters, v. 3, n. 3, p. 228-235, 2000.

ENNIS, D. E. et al. Simulated roots and host feeding enhance infection of subterranean insects by the entomopathogenic nematode Steinernema carpocapsae. Journal of Invertebrate Pathology, v. 103, n. 2, p. 140143, 2010.

GAUGLER, R.; LEWIS, E.; STUART, R. J. Ecology in the service of biological control: the case of entomopathogenic nematodes. Oecologia, v. 109, n. 4, p. 483-489, 1997.

GREWAL, P. S.; NARDO, E. A. B. de; AGUILLERA, M. Entomopathogenic nematodes: potential for exploration and use in South America. Neotropical Entomology, v. 30, n. 2, p. 191-205, 2001.

GRIFFIN, C. T. Perspectives on the behavior of entomopathogenic nematodes from dispersal to reproduction: traits contributing to nematode fitness and biocontrol efficacy. Journal of Nematology, v. 44, n. 2, p. 177-184, 2012.

HALLEM, E. A. et al. A sensory code for host seeking in parasitic nematodes. Current Biology, v. 21, n. 5, p. 377383, 2011. 
HILTPOLD, I. et al. How maize root volatiles affect the efficacy of entomopathogenic nematodes in controlling the western corn rootworm? Chemoecology, v. 20, n. 2 , p. $155-162,2010$.

HILTPOLD, I.; TURLINGS, T. C. J. Manipulation of chemically mediated interactions in agricultural soils to enhance the control of crop pests and to improve crop yield. Journal of Chemical Ecology, v. 38, n. 6, p. 641650, 2012.

KRUITBOS, L. M. et al. The influence of habitat quality on the foraging strategies of the entomopathogenic nematodes Steinernema carpocapsae and Heterorhabditis megidis. Parasitology, v. 137, n. 2, p. 303-309, 2010.

LEWIS, E. E. et al. Behavioral ecology of entomopathogenic nematodes. Biological Control, v. 38, n. 1, p. 66-79, 2006.

LEWIS, E. E. et al. Hierarchical order of host cues in parasite foraging strategies. Parasitology, v. 110, n. 2, p. 207-213, 1995 .

PARRA, J. R. P. Criação de insetos para estudos com patógenos. In: ALVES, S. B. Controle microbiano de insetos. Piracicaba: Fealq, 1998. p. 1015-1037.

RAMOS-RODRIGUEZ, O. et al. Attraction behavior of three entomopathogenic nematode species towards infected and uninfected hosts. Parasitology, v. 134, n. 5, p. 729-738, 2007.

RASMANN, S. et al. Direct and indirect root defenses of milkweed (Asclepias syriaca): trophic cascades, trade-offs and novel methods for studying subterranean herbivory. Journal of Ecology, v. 99, n. 1, p. 16-25, 2011.

RASMANN, S. et al. Ecology and evolution of soil nematode chemotaxis. Journal of Chemical Ecology, v. 38, n. 6, p. 615-628, 2012.
RASMANN, S. et al. Recruitment of entomopathogenic nematodes by insect-damaged maize roots. Nature, v. 434, n. 7034, p. 732-737, 2005.

SHAPIRO-ILAN, D. et al. Directional movement of steinernematid nematodes in response to electrical current. Journal of Invertebrate Pathology, v. 100, n. 2, p. 134137, 2009.

TORR, P.; HERITAGE, S.; WILSON, M. J. Vibrations as a novel signal for host location by parasitic nematodes. International Journal of Parasitology, v. 34, n. 9, p. 997999, 2004.

TURLINGS, T. C. J. et al. The importance of rootproduced volatiles as foraging cues for entomopathogenic nematodes. Plant Soil, v. 358, n. 1-2, p. 51-60, 2012.

TURLINGS, T. C. J. et al. Volicitin, an elicitor of maize volatiles in the oral secretion of Spodoptera exigua: its isolation and bioactivity. Journal of Chemical Ecology, v. 26, n. 1, p. 189-202, 2000.

TURNER, S. L. et al. Ultra-prolonged activation of $\mathrm{CO}_{2}-$ sensing neurons disorients mosquitoes. Nature, v. 474, n. 7349, p. 87-91, 2011.

VAN TOL, R. W. H. M. et al. Plants protect their roots by alerting the enemies of grubs. Ecology Letters, v. 4, n. 4, p. 292-294, 2001.

WALTON, J. D. Biochemical plant pathology. In: DEY, P. M.; HARBORNE, J. B. Plant biochemistry. San Diego: Academic Press, 1997. p. 487-502.

WILSON, M. J. et al. Entomopathogenic nematode foraging strategies: is Steinernema carpocapsae really an ambush forager? Nematology, v. 14, n. 4, p. 389-394, 2012 . 